\title{
ANTI-LEPTOSPIRA SPP AND ANTI-BRUCELLA SPP ANTIBODIES IN HUMANS FROM RURAL AREA OF MONTE NEGRO MUNICIPALITY, STATE OF RONDÔNIA, BRAZILIAN WESTERN AMAZON
}

\author{
Daniel M. Aguiar ${ }^{1,2}$; Guacyara T. Cavalcante²; Luis M. A. Camargo ${ }^{3}$; Marcelo B. Labruna ${ }^{2}$; Silvio A. Vasconcellos ${ }^{2}$; \\ Gisele O. Souza ${ }^{2}$; Solange M. Gennari ${ }^{2}$ \\ ${ }^{1}$ Agência Paulista de Tecnologia do Agronegócio (APTA), Pólo Regional de Desenvolvimento Tecnológico da Alta \\ Sorocabana, Presidente Prudente, SP; ${ }^{2}$ Departamento de Medicina Veterinária Preventiva e Saúde Animal, Faculdade de \\ Medicina Veterinária e Zootecnia da Universidade de São Paulo, Brasil; ${ }^{3}$ Instituto de Ciências Biomédicas V, Núcleo avançado \\ de pesquisa de Monte Negro, RO. Universidade de São Paulo, Brasil
}

Submitted: April 10, 2006; Returned to authors for corrections: July 06, 2006; Approved: October 13, 2006

\begin{abstract}
Sera from 276 humans living in 71 farms located in Monte Negro Municipality, RO., Western Amazon, Brazil were examined for anti-Leptospira spp antibodies by Microscopic Agglutination Test and for anti-Brucella spp antibodies by Tube Agglutination Test. Leptospira spp antibodies were detected in 28 (10.2\%) of them with at least one positive case in 23 farms (32.4\%). The most frequent leptospira serovars were Patoc (46.7\%), Autumnalis $(10.0 \%)$ and Shermani $(10.0 \%)$. The proportion of positive males (14.5\%) were higher than females $(5.0 \% ; P<0.05)$ and the contact with river water presented association with Leptospira spp infection (OR: 27; $P=0.01)$. A total of 04 (1.4\%) humans reacted against Brucella antigens; three farms (4.2\%) presented at least one positive case of brucellosis.
\end{abstract}

Key-words: Human, Leptospirosis, Brucellosis, Amazon, Brazil

\section{INTRODUCTION}

Leptospirosis and brucellosis are important zoonoses affecting humans and domestic animals all over the world. Leptospirosis occurs in urban and rural areas in both tropical and temperate regions and is an occupational hazard for those who work outdoor or with animals and as a recreational hazard for those who swim or wade in contaminated waters and inundations (12). In Brazil 4,128 cases were recorded in 2000, according to the National Fundation of Health (17). Prevalence of the brucellosis diverge widely from country to country, in Brazil, it was not regularly verified but the consumption of contaminated food and occupational contact remain as the major sources of infection (4).

The Brazilian Amazon region is a new frontier where agricultural development and livestock activities have been attempted. The state of Rondônia is a developing area in the western Amazon of Brazil, where it is not available enough information about the occurrence of some zoonoses. This region is a typical frontier of human occupation, where the human inhabitants, domestic and wild animals share the same habitat, and also pathogenic microrganisms (10). The present study examineted the seroprevalence and risk factors associated with Leptospira spp and Brucella spp infections in humans of the rural area of Monte Negro Municipality, Rondônia state, Western Amazon, Brazil.

\section{MATERIALAND METHODS}

Monte Negro Municipality, located in Rondônia state, Western Amazon, Brazil (10 $15^{\prime} 35^{\prime \prime} \mathrm{S}, 63^{\circ} 18^{\prime}$ 06"W), has population of approximately 13,000 inhabitants, most of them rural dwellers in small, family-employed farms. The region has a high rainfall index that averages 2,000 $\mathrm{mm}$ per year; there is a

*Corresponding Author. Mailing address: Rod. Raposo Tavares, Km 563, Cx.P. 298, CEP: 19015-970; Presidente Prudente /SP.; Tel: (18) $3222-8886$ ou (18) 3222-8688. E-mail: danmoura@ aptaregional.sp.gov.br 
moderate drought period during April-October. Temperature ranges from 25 to $29^{\circ} \mathrm{C}$ and the relative humidity is $70 \%-80 \%$ throughout the year. From 722 cattle farms registered in the area surveyed, 86 were randomly selected using an estimated prevalence of $50 \%$, absolute precision of $10 \%$ and confidence interval of $95 \%$. The people living in those farms were invited to collaborate in this study. In 71 farms it was obtained the permission for blood sample collection.

Serum samples were collected from 276 humans from May to October 2002 and stored at $-20^{\circ} \mathrm{C}$ until serologic analysis. During the visit to each farm, a questionnaire was applied to identify possible independent variables associated with seropositivity. The variables questioned were based on the regional characteristics regarding the water source, contact with domestic animals (dog, pig, and horse) and production herdtype of cattle (dairy, beef or mixed).

Serum samples were examined for leptospirosis by Microscopic Agglutination Test (MAT) $(3,5)$ with the cut off 1:100 dilution against 24 leptospira serovars cultivated in modified EMJH medium (2). Positive sera were retested against each reactant serovar in two fold serial dilutions. The most probable serovar was the one that presented the highest titer. For brucellosis, serum samples were examined by Tube Agglutination Test (SAT) (1). The antigen used was an inactive suspension of $B$. abortus 1119-3 produced by the Institute of Technology of Paraná, Brazil. Reactions were considered positive when a titer of at least 80 was detected.

The variables identified in the questionnaire were subjected to univariate analysis and those with statistical association $\left(P<0.20\right.$ in Qui-square test $\left(\chi^{2}\right)$ or Fischer's exact test $)$ were tested in the multivariate model by the stepwise forward method (8). Variables were included in the multivariate model if they displayed statistical significance of $P<0.05$. Analyses were performed using SPSS for Windows (1999). For evaluation of the differences between age groups and sex occurrence, the $\chi^{2}$ was used with EpiInfo version 6.0.

\section{RESULTS}

Leptospira spp antibodies were detected in $28(10.2 \%$; $95 \%$ CI: $7-14 \%$ ) of the 276 sera against one or more serovar with MAT titers of 100 in ten, 200 in 12, 400 in four and 800 in two. From the 71 farms examined, 23 (32.4\%; 95\% CI: $22-44 \%$ ) had at least 1 seropositive person. In relation to age, no difference were observed $\left(\chi^{2}=3.2 ; P=0.07\right)$ (Table 1$)$, however there was significant difference in the seroprevalence of male $14.5 \%$ (21/ 144) and female $5.0 \%\left(07 / 132 ; \chi^{2}=6.2 ; P=0.01\right)$. The serovars Patoc, Autumnalis and Shermani were the most prevalent (Table 2). Four (1.4\%; 95\% CI: $0.4-3.4 \%$ ) humans reacted against Brucella antigens with SAT beings two titers of 80 (two males; with 30 and 72 years old) and two titers of 160 (one male with 20 years old and one female with 24 years old). In only three farms
Table 1. Antibody titers to Leptospira spp by age groups in sera of 276 humans of the rural area from Monte Negro Municipality, Rondônia State, Brazilian Western Amazon, by the Microscopic Agglutination Test (MAT).

\begin{tabular}{ccccccc}
\hline \multirow{2}{*}{$\begin{array}{c}\text { Age } \\
\text { (years) }\end{array}$} & \multirow{2}{*}{$\begin{array}{c}\text { No. } \\
\text { tested }\end{array}$} & \multirow{2}{*}{$\begin{array}{c}\text { No. positive } \\
(\%)\end{array}$} & \multicolumn{5}{c}{ MAT titers } \\
\cline { 4 - 8 } & & 100 & 200 & 400 & 800 \\
\hline $0-6$ & 21 & 0 & 0 & 0 & 0 & 0 \\
$7-12$ & 30 & $03(10.7)$ & 0 & 03 & 0 & 0 \\
$13-19$ & 49 & $02(7.3)$ & 0 & 02 & 0 & 0 \\
$20-40$ & 76 & $11(39.2)$ & 03 & 05 & 02 & 01 \\
$>40$ & 100 & $12(42.8)$ & 07 & 02 & 02 & 01 \\
\hline Total & 276 & 28 & 10 & 12 & 04 & 02 \\
\hline
\end{tabular}

Table 2. Seroprevalence according to different Leptospira serovars among humans of the rural area from Monte Negro Municipality, Rondônia State, Brazilian Western Amazon.

\begin{tabular}{lcc}
\hline \multirow{2}{*}{ Serovar } & \multicolumn{2}{c}{ Positive sample } \\
\cline { 2 - 3 } & $\mathrm{N}$ & $\%$ \\
\hline Patoc & 14 & 46.7 \\
Autumnalis & 03 & 10.0 \\
Shermani & 03 & 10.0 \\
Pomona & 02 & 6.7 \\
Hardjo & 01 & 3.33 \\
Bratislava & 01 & 3.33 \\
Pyrogenes & 01 & 3.33 \\
Canicola & 01 & 3.33 \\
Copenhageni & 01 & 3.33 \\
Icterohaemorrhagiae & 01 & 3.33 \\
Others serovars* & 0 & 0 \\
Not characterized serovars & 2 & 6.7 \\
\hline Total & 30 & 100 \\
\hline * Hebdomadis, Wolffi, Grippothyphosa, Panama, Butembo, \\
Whitcombi, Australis, Castellonis, Andamana, Cinoptery, Sentot, \\
Tarassovi, Bataviae, Javanica.
\end{tabular}

(4.2\%; 95\% CI: $1-11 \%)$ there were at least one seropositive, and for that reason the statistical analysis was not accomplished. The results of univariate and multivariate analysis for Leptospira spp are presented in Table 3.

\section{DISCUSSION}

This is the first serological survey of the infection by Leptospira spp and Brucella spp in humans from the rural areas 
Table 3. Statistical analyses of association between studied variables and presence of antibody anti-Leptospira spp in humans from rural area from Western Amazon, Brazil.

\begin{tabular}{|c|c|c|c|c|c|c|c|c|}
\hline \multirow{3}{*}{ Variables } & \multicolumn{3}{|c|}{ Farms } & \multicolumn{5}{|c|}{ Analysis } \\
\hline & \multirow[t]{2}{*}{ Sampled } & \multirow[t]{2}{*}{ Positive } & \multirow[t]{2}{*}{$\%$} & \multicolumn{2}{|c|}{ Univariate } & \multicolumn{3}{|c|}{ Multivariate } \\
\hline & & & & $\dot{\div}^{2}$ & $P$ & $\mathrm{OR}$ & $P$ & $95 \% \mathrm{CI}$ \\
\hline \multicolumn{9}{|l|}{ Water for work } \\
\hline Well & 38 & 10 & 26.0 & & & & & \\
\hline River & 07 & 05 & 71.4 & 5.4 & 0.02 & 27.0 & 0.01 & $2.8-351.0$ \\
\hline \multicolumn{9}{|c|}{ Hunting consumption } \\
\hline No & 29 & 06 & 20.0 & & & & & \\
\hline Yes & 39 & 16 & 41.0 & 3.1 & 0.07 & 1.7 & 0.20 & \\
\hline \multicolumn{9}{|l|}{ Dairy farms } \\
\hline No & 28 & 07 & 25.0 & & & & & \\
\hline Yes & 43 & 16 & 37.2 & 1.15 & 0.28 & & & \\
\hline \multicolumn{9}{|l|}{ Beef farms } \\
\hline No & 63 & 20 & 31.7 & & & & & \\
\hline Yes & 08 & 03 & 37.5 & 0.23 & 0.74 & & & \\
\hline \multicolumn{9}{|l|}{ Mixed farms } \\
\hline No & 51 & 18 & 35.2 & & & & & \\
\hline Yes & 20 & 05 & 25.0 & 0.70 & 0.40 & & & \\
\hline \multicolumn{9}{|l|}{ Dog presence } \\
\hline No & 07 & 03 & 42.8 & & & & & \\
\hline Yes & 64 & 20 & 31.2 & 0.53 & 0.67 & & & \\
\hline \multicolumn{9}{|l|}{ Pig Presence } \\
\hline No & 29 & 08 & 27.5 & & & & & \\
\hline Yes & 42 & 15 & 35.7 & 0.51 & 0.47 & & & \\
\hline \multicolumn{9}{|l|}{ Horse presence } \\
\hline No & 06 & 01 & 16.6 & & & & & \\
\hline Yes & 65 & 22 & 34.0 & 0.55 & 0.65 & & & \\
\hline
\end{tabular}

of the Western Amazon, Brazil. Our study indicated that the prevalence of anti-Leptospira spp antibodies in humans beings was $10.2 \%$ and $32.4 \%$ of the farms presented at least one seropositive sample. The farm seroprevalence in the present study was similar as found by Homem et al. (6) in the Eastern Brazilian Amazon. Most tropical countries are also developing countries, and there are great opportunities for exposure of human population to infected animals, whether livestock, domestic pets, or wild or feral animals. Additionally, the incidence of human leptospirosis is significantly higher in warms-climates countries than in temperate regions. According to WHO, it probably ranges from 0.1 to 1 per 100 per year in temperate climates to 10 or more per 100 per year in the humid tropics (17).

The occurrence of leptospira antibodies in males (14.5\%) was higher than in females $(5.0 \%-P<0.05)$. Maybe because, males have more probability of acquiring the infection at work. The contact with river water was the variable that presented the hightest association with Leptospira spp infection. In this survey, Leptospira spp prevalence had no association with presence of domestic animals, however, water-born transmission have been documented, and agree with Levett (12) who pointed water contamination as responsible for several leptospirosis outbreaks.

The serovar Patoc was the most prevalent. This serovar belongs to the Leptospira biflexa group and is frequently used in serological investigations as genus specific antigen, because it presents crossed-reactions with pathogenic serovars and could detected antibodies earlier in the infection course by pathogenic serovar (13). The second more prevalent serovar were Autumnalis and Shermani. Few studies in Brazil described 
the occurrence of Autumnalis in humans from north region as well the serovar Shermani that is maintained by wild rodents and has frequently been found in serological studies in cattle and humans from the northern area of Brazil $(14,6)$. Other serovars worldwidely reported in rural areas like Pomona, Hardjo, Bratislava, and Pyrogenes were detected in low levels.

Antibodies against Brucella spp was found in 04 (1.4\%) people from 03 (4.2\%) farms. In the Eastern Brazilian Amazon, Homem et al. (7) found a higher prevalence of up to $29 \%$ among the studied farms. The true incidence of human brucellosis is unknown. Reported incidence in endemic disease areas varies widely, from $<0.01$ to $>200$ per 100,000 population (4). In Brazil human brucellosis is caused mainly by $B$. abortus and $B$. suis $(15,16)$. Most cases of human brucellosis were essentially an occupational hazard, occurring primarily in abattoir workers and meat processors (9). Additionally, the consumption of unpasteurized fresh cheese is very common and could be another way of transmission for humans $(11,15)$.

\section{ACKNOWLEDGEMENTS}

To Fundação de Amparo à Pesquisa do Estado de São Paulo (FAPESP) for the financial support. D. M. Aguiar, S. A. Vasconcellos, M. B. Labruna and S. M. Gennari are in receipt of a scholarship from Conselho Nacional de Desenvolvimento Científico e Tecnológico and G.T. Cavalcante from Coordenação de Aperfeiçoamento de Pessoal de Nível Superior.

\section{RESUMO}

\section{Anticorpos anti-Leptospira spp e anti-Brucella spp em humanos da área rural do município de Monte Negro, estado de Rondônia, Amazônia Ocidental Brasileira}

Foram avaliados soros de 276 humanos procedentes de 71 fazendas localizadas no município de Monte Negro, RO, pela Soroaglutinação Microscópica para verificar a presença de anticorpos anti-Leptospira spp e pela Soroaglutinação Lenta em Tubos para verificar a presença de anticorpos anti-Brucella spp. Anticorpos anti-Leptospira spp foram detectados em 28 $(10,2 \%)$ humanos procedentes de 23 fazendas $(32,4 \%)$. Os sorovares mais freqüentes foram Patoc $(46,7 \%)$, Autumnalis $(10,0 \%)$ e Shermani $(10,0 \%)$. A positividade foi maior no sexo masculino $(14,5 \%)$ que no feminino $(5,0 \% ; P<0,05)$ e o contato com a água de rio apresentou associação com a infecção por Leptospira spp (OR: 27; $P<0,05)$. Quatro humanos $(1,4 \%)$ reagiram contra antígenos de Brucella spp, com três $(4,2 \%)$ fazendas apresentando pelo menos uma reação positiva para Brucella spp.

Palavras-chaves: Humanos, Leptospirose, Brucelose, Amazônia, Brasil

\section{REFERENCES}

1. Alton, G.G.; Jones, L.M.; Pietz, D.E. (1976). Las técnicas de laboratorios en la brucellosis. Organización Mundial de la Salud, Ginebra.

2. Alves, C.J.; Vasconcellos, S.A.; Camargo, C.R.A.; Morais, Z.M. (1996). Influência de fatores ambientais sobre a proporção de caprinos soro-reatores para a leptospirose em cinco centros de criação do estado da Paraíba, Brasil. Arq. Inst. Biol., 63, 11-18.

3. Cole Junior, J.R.; Sulzer, C.R.; Pursell, A.R. (1973). Improved Microtechnique for the Leptospiral Microscopic Agglutination Test. Appl. Microbiol., 25, 970-980.

4. Corbel, M.J. (1997). Brucellosis: an overview. Emerg. Infect. Diseases, 3, 213-221.

5. Galton, M.M.; Sulzer, C.R.; Santa Rosa, C.A.; Fields, M.J. (1965). Application of a Microtechnique to the Agglutination Test for Leptospiral Antibodies. Appl. Microbiol., 13, 81-85.

6. Homem, V.S.F.; Heinemann, M.B.; Moraes, Z.M.; Vasconcellos, S.A.; Ferreira, F.; Ferreira Neto, J.S. (2001). Estudo epidemiológico da leptospirose bovina e humana na Amazônia Oriental brasileira. Rev. Soc. Bras. Med. Trop., 34, 173-180.

7. Homem, V.S.F.; Heinemann, M.B.; Moraes, Z.M.; Veiga, J.B.; Lau, H.D.; Tourrand, J.F.; Ferreira, F.; Ferreira Neto, J.S. (1993). Some zoonoses in the Eastern Amazon. Case of Uruará, Brazil. X International Congress on Animal Hygiene, Maastricht, Netherlands, p.204-210.

8. Hosmer Jr, D.W.; Lemeshow, S. (2000). Applied logistic Regression. Wiley-Interscience Press, New York.

9. Lacerda, L.M.; Alves, L.M.C.; Mathias, L.A.; Rodrigues, A.L.B.; Almeida, F.M. (1997). Brucelose em trabalhadores de matadouros do município de São Luis, MA. Hig. Aliment., 14, 62-65.

10. Labruna, M.B.; Camargo, L.M.; Schumaker, T.T.; Camargo, E.P. (2002). Parasitism of domestic swine (Sus scrofa) by Amblyomma ticks (acari: Ixodidae) on a farm at Monte Negro, western Amazon, Brazil. J. Med. Entomol., 39, 241-243.

11. Langoni, H.; Ichihara, S.M.; Silva, A.V.; Pardo, R.B.; Tonin, F.B.; Mendonça, L.J.P.; Machado, J.A.D. (2000). Isolamento de Brucella spp do leite de vacas positivas para brucelose nos estados de São Paulo e Minas Gerais. Braz. J. Vet. Res.An. Sce., 37, 444-448.

12. Levett, P.N. (2001). Leptospirosis. Clin. Microbiol. Rev., 14, 296326.

13. Mauermann, U.; Wiegand, D.; Manz, D. (1993). Use of nonpathogenic Leptospira strains as diagnostic antigens for detection of Leptospira infection in cattle. Germany. Berliner und Munch. Tierarzt. Wochenschr., 106, 296-299.

14. Negrão, A.M.G.; Molnár, E.; Molnár, L. (1999). Dados sorológicos da leptospirose bovina em algumas regiões do estado do Pará. Rev. Bras. Reprod. Anim., 23, 406-407.

15. Poester, F.P.; Gonçalves, V.S.P.; Lage, A.P. (2002). Brucellosis in Brazil. Vet. Microbiol., 90, 55-62.

16. Roxo, E.; Bersano, J.G.; Portugal, M.A.S.C. (1996). Brucella suis em diversas espécies de animais numa mesma propriedade. Arq. Inst. Biol., 63, 11-14.

17. Massarani, L. (2004). Brazilian Genomic Break-through offers hope for Leptospirosis control $W H O, 82,471$. 